\title{
Grand Canyon Humpback Chub Population Improving
}

The humpback chub (Gila cypha) (fig. 1) is a long-lived, freshwater fish found only in the Colorado River Basin. Physical adaptations-large adult body size, large predorsal hump, and small eyes-appear to have helped humpback chub evolve in the historically turbulent Colorado River. A variety of factors, including habitat alterations and the introduction of nonnative fishes, likely prompted the decline of native Colorado River fishes. Declining numbers propelled the humpback chub onto the Federal list of endangered species in 1967, and the species is today protected under the Endangered Species Act of 1973. Only six populations of humpback chub are currently known to exist, five in the Colorado River Basin above Lees Ferry, Ariz., and one in Grand Canyon, Ariz.

The U.S. Geological Survey's (USGS) Grand Canyon Monitoring and Research Center oversees monitoring and research activities for the Grand Canyon population under the auspices of the Glen Canyon Dam Adaptive Management Program (GCDAMP). Analysis of data collected through 2006 suggests that the number of adult (age 4+ years) humpback chub in Grand Canyon increased to approximately 6,000 fish in 2006, following an approximate 40-50 percent decline between 1989 and 2001 (Coggins, 2007). Increasing numbers of adult fish appear to be the result of steadily increasing numbers of juvenile fish reaching adulthood beginning in the mid- to late-1990s and continuing through at least 2002 (Coggins, 2007).

\section{Background}

The majority of Grand Canyon humpback chub are found in the Little Colorado River (the largest tributary to the Colorado River in Grand Canyon) and in the Colorado River near its confluence with the Little Colorado River (Paukert and others, 2006). The vast majority of these fish are produced in the Little Colorado River because mainstem Colorado River temperatures are generally too cold for spawning. Humpback chub require a minimum temperature of $16^{\circ} \mathrm{C}\left(60.8^{\circ} \mathrm{F}\right)$ to reproduce (Hamman, 1982). Today, because the release structures of Glen Canyon Dam are well below the surface of Lake Powell, where the warmth of the sun cannot penetrate, Colorado River temperatures in Grand Canyon range from $7^{\circ} \mathrm{C}$ to $12^{\circ} \mathrm{C}\left(44.6^{\circ} \mathrm{F}-53.6^{\circ} \mathrm{F}\right)$.

Humpback chub have been affected not only by changes in hydrology since the construction of the dam but also by competition with and predation by nonnative fishes. Fishes originating in many parts of the world are currently found in the Colorado River, including introduced species of trout, catfish, carp, and bass. Nonnative fish parasites, such as the Asian tapeworm (Bothriocephalus acheilognathi) and anchor worm

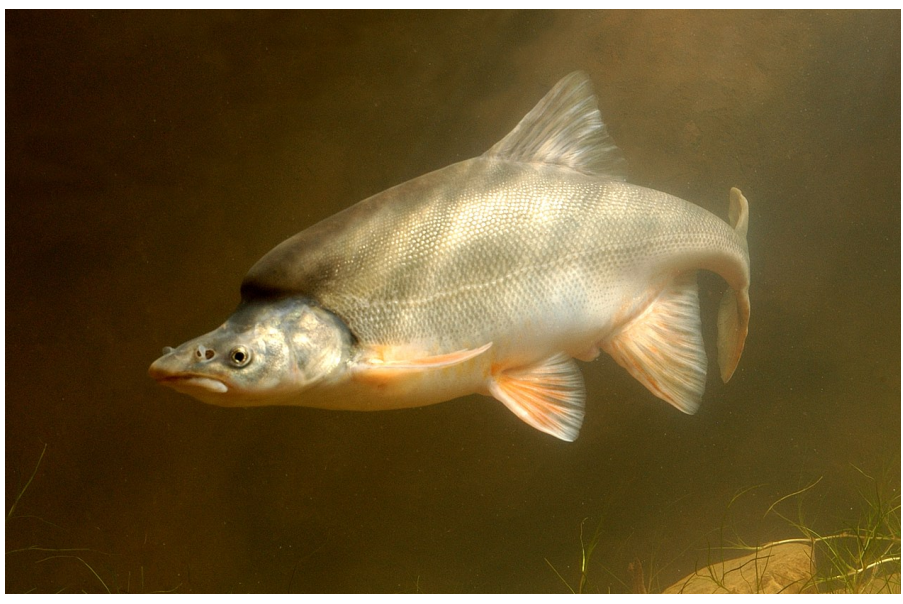

Figure 1. The humpback chub (Gila cypha) is an endangered freshwater fish found only in the Colorado River Basin. Analysis of recently collected data indicates that the number of adult fish (age 4+ years) in Grand Canyon increased to 6,000 following years of decline (photograph courtesy of Arizona Game and Fish Department).

(Lernaea cyprinacea), which infect some humpback chub, have also found their way into the Colorado River.

Since 1989, when scientists began repeated monitoring efforts, the population of adult humpback chub in Grand Canyon has declined steadily until about 2001 (fig. 2.), when the population appeared to stabilize. More recently, the population appears to have increased, reaching an estimated 6,000 adult fish in 2006. Current estimates suggest that there has been an approximate increase of 20-25 percent in adult fish abundance since 2001 (Coggins, 2007). This increase in adult fish numbers since 2001 appears to be the result of increasing recruitment that began in the mid- to late-1990s and has continued through at least 2002.

\section{Improved Assessment Procedures}

USGS scientists have been working to improve their ability to estimate the status and trends of the Grand Canyon population of humpback chub. They evaluated the age-structured mark-and-recapture models used to estimate adult humpback chub numbers and made refinements to ensure that current estimates are most consistent with the data (Coggins, 2007). Model innovations included accounting for the impacts of seasonal and spatial variation in water temperature on fish growth. A new method was also developed for estimating the relation between fish age and length (Coggins, 2007). Scientists also concluded 


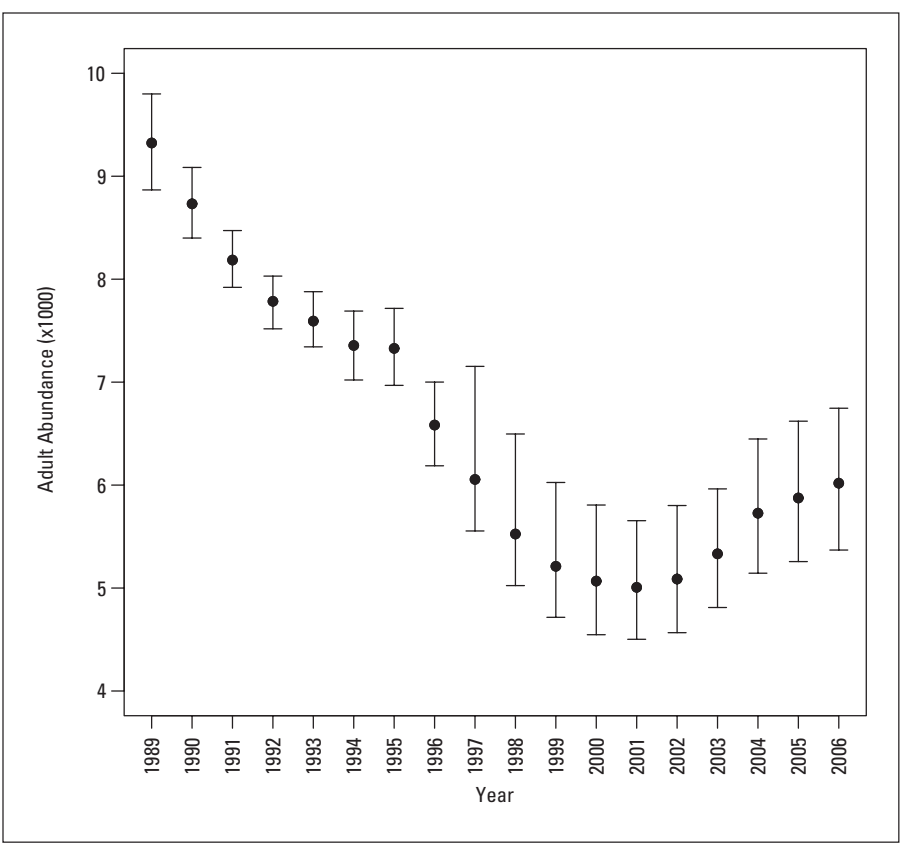

Figure 2. Adult (age 4+ years) humpback chub population estimates (1989-2006) for the Grand Canyon population. Error bars represent 95 percent confidence intervals (from Coggins, 2007).

that only large changes in recruitment caused by management actions can be readily detected, given the uncertainty in current assessment procedures.

\section{Discussion}

The phenomena that may be causing recent increases in adult humpback chub numbers in Grand Canyon are uncertain. Scientists hypothesize that the fish may have benefited from several factors, including the experimental water releases from Glen Canyon Dam, removal of nonnative fish, and drought-induced warming.

Humpback chub produced in 1999, which are now adults, may have benefited from substantial in-stream warming as the result of the 2000 low steady flow experiment. In the summer of 2000, as a result of the experiment, peak water temperatures in some parts of Grand Canyon exceeded $20^{\circ} \mathrm{C}\left(68.5^{\circ} \mathrm{F}\right)$, which represents a temperature increase when compared with typical peak temperatures of $15^{\circ} \mathrm{C}-18^{\circ} \mathrm{C}\left(59^{\circ} \mathrm{F}-64^{\circ} \mathrm{F}\right)$ in recent years. Additionally, experimental high flows released in 1996, 1997, 2000, and 2004 may have disadvantaged nonnative fish and improved humpback chub habitat (Valdez and others, 2001).

Beginning in 2003, large numbers of rainbow trout (Oncorhynchus mykiss) and brown trout (Salmo trutta) were removed from the area near the confluence of the Colorado and Little Colorado Rivers. Rainbow and brown trout are thought to compete with humpback chub for food and to prey on young fish. Between 2003 and 2006 the rainbow trout population in the Colorado River near the Little Colorado River was reduced by more than 80 percent (U.S. Geological Survey, unpub. data, 2007). Other nonnative fish species were also removed as part of this effort.

Since 2003, water temperatures below Glen Canyon Dam increased as the result of drought conditions. As drought has reduced flows into Lake Powell, the level of the reservoir has dropped, allowing warmer water found closer to the surface of the reservoir to reach the release structures. In 2005, water temperatures in the mainstem Colorado River near the Little Colorado River exceeded $17^{\circ} \mathrm{C}\left(60.8^{\circ} \mathrm{F}\right)$, the warmest temperatures recorded since the reservoir filled in 1980 and approximately the minimum temperature needed by humpback chub to successfully reproduce. Native fish are thought to benefit from warmer water releases; however, there is great concern that warmer water temperatures may also benefit nonnative warmwater fish like the channel catfish (Ictalurus punctatus) and other voracious predators.

Scientists do not know if experimental activities, the natural warming of the river, or other factors such as improved rearing conditions in the Little Colorado River are most responsible for increases in recruitment and survival of humpback chub. Continued monitoring of humpback chub, other species, and habitat conditions will be necessary to establish cause-andeffect relationships.

The Glen Canyon Dam Adaptive Management Program was established to monitor and analyze the effects of dam operations on downstream resources and to use these assessments to recommend to the Secretary of the Interior adjustments intended to improve the values for which the Glen Canyon National Recreation Area and Grand Canyon National Park were established. Fieldwork related to humpback chub research was conducted cooperatively by the USGS and GCDAMP partners, including the Arizona Game and Fish Department and the U.S. Fish and Wildlife Service.

\section{References}

Coggins, L.G., 2007, Abundance trends and status of the Little Colorado River population of humpback chub; an update considering 1989-2006 data: U.S. Geological Survey Open-File Report 2007-1402, 53 p.

Hamman, R.L., 1982, Spawning and culture of humpback chub: Progressive Fish-Culturist, v. 44, no. 4, p. 213-216.

Paukert, C.P., Coggins, L.G., and Flaccus, C.E., 2006, Distribution and movement of humpback chub in the Colorado River, Grand Canyon, based on recaptures: Transactions of the American Fisheries Society, v. 135, p. 539-544.

Valdez, R.A., Hoffnagle, T.L., McIvor, C.C., McKinney, T., and Leibfried, W.C., 2001, Effects of a test flood on fishes of the Colorado River in Grand Canyon, Arizona: Ecological Applications, v. 11, no. 3, p. 686-700.

\section{More Information}

Matthew E. Andersen

U.S. Geological Survey

Southwest Biological Science Center

Grand Canyon Monitoring and Research Center

Tel: 928-556-7094

E-mail: mandersen@usgs.gov

Website: www.gcmrc.gov 